\title{
The Elephant in the Room: How COVID-19's Financial Impact Further Threatens Title IX Compliance
}

\author{
Karen L. Hartman \\ Idaho State University
}

\begin{abstract}
This scholarly commentary addresses COVID-19's financial impact by examining how current and proposed National Collegiate Athletic Association bylaw waivers could negatively affect women's collegiate athletics and Title IX compliance. These potential bylaw changes come after years of misinformation, a lack of education, and minimal understanding of the law. In the chaos of COVID-19's impact on American society and athletic programs, Title IX has become the elephant in the room. The essay concludes with three recommendations that could help athletic departments alleviate Title IX compliance issues when enacting the bylaw waivers.
\end{abstract}

Keywords: bylaw waivers, compliance, NCAA, women athletes

The economic fallout from COVID-19 on U.S. collegiate athletic departments is a top administrative concern. So much so that on April 9, commissioners from five National Collegiate Athletic Association (NCAA) Division I conferences sent a letter to Mark Emmert, the association's president, to request leniency from several NCAA regulations. The commissioners noted a need for flexibility due to potential COVID-19 financial challenges, such as decreased state appropriation funding, lower philanthropic giving, and reduced enrollment. One week later, 22 schools belonging to the Collegiate Commissioners Association also submitted a letter seeking regulatory relief. By the end of April, the majority of Division I conferences requested consideration for waivers and relaxed regulations (Hosick, 2020b). These requests suggest the depth of financial strain many Division I programs feel as well as their view that relaxing regulations is a way to survive.

Conferences and athletic departments are desperate to keep revenue coming in, limit costs, and simply survive. The COVID-19 financial challenges, however, follow years of financial strain. While athletics are perceived to bring in millions of dollars, any school making a profit is in the minority (Burnsed, 2015). For example, in 2014, only 24 Football Bowl Subdivision (FBS) programs profited. Although many football and men's basketball programs produce revenue, the profits are nonexistent for the majority of schools. In addition, in the first few months

The author (hartkar2@isu.edu) is with the Dept. of Communication, Media, \& Persuasion, Idaho State University, Pocatello, ID, USA. 
following the COVID-19 outbreak, schools have already cut sports as a cost-saving measure. By May 26, 20 men's and women's Division I programs had been eliminated (Beard, 2020). Therefore, providing waivers and reducing regulations for NCAA members has been a popular idea among Division I programs to, at least, find some way to survive. But, if this is their best idea, who benefits and who loses? For thousands of women athletes, they could lose.

This scholarly commentary addresses COVID-19's financial impact by examining how current and proposed NCAA bylaw waivers could negatively affect women's collegiate athletics and Title IX compliance. In the chaos of COVID-19's impact on American society and athletic programs, Title IX has become the elephant in the room. It is imperative that commissioners, coaches, and athletic directors as well as communication and sport scholars recognize how certain bylaw waivers could have negative consequences. These potential changes come after years of misinformation, a lack of education, and minimal understanding of the law. Although coaches desire more meaningful discussions about Title IX, most do not understand the law at a basic level. There is scant research on which university athletics departments have had formal education on Title IX's enforcement, and while all universities can have a Title IX compliance officer, not all do (Staurowsky \& Weight, 2011). More should be done to educate university officials and scholars about Title IX, and this essay hopes to do so during a pivotal time for collegiate athletics.

\section{Title IX and Media Coverage}

Title IX, part of the Education Amendments Act of 1972, prevents sex discrimination for institutions receiving federal funding. Within college athletics, universities have three ways to comply. Known as the three-prong test, universities can choose any one prong to demonstrate compliance with the law: substantial proportionality, demonstrating a history of expanding opportunities for the underrepresented sex, or fully meeting the demonstrated interest and abilities of the underrepresented sex. Since the law's implementation, participation rates for both men and women from the high school to the collegiate level have increased, but compliance is still dramatically off. In 2017, an estimated 201 Division I programs and 815 out of 1,085 institutions at all Division I, II, and III levels were out of compliance with Title IX (Jenkins, 2019).

The latest bylaw waiver requests have not appeared to ring any alarm bells in terms of Title IX. A search conducted on Nexis Uni using the terms "NCAA" and "waiver" with dates spanning from April 9 to May 13 produced 671 articles. Once duplicates and irrelevant articles were removed (e.g., articles on the Nigerian Civil Aviation Act), 265 relevant articles remained. The dates were chosen as April 9 was when the letter from the five commissioners was written and the time span provided 35 days to review articles responding to the waiver request. Furthermore, a drop in the number of news articles on NCAA waivers was seen by May 13, suggesting that the story had reached the end of its relevant news cycle. For example, from May 11 to May 13, the number of relevant articles dropped to six. Conducting a similar search and adding the term "Title IX" provided 14 articles. Out of these, four were duplicates, resulting in 10 relevant and unique articles. A content analysis of each of the 10 articles found that they referenced 
Title IX in relation to sport sponsorship (six), tuition waivers (one), spring sport eligibility (one), or a Title IX investigation against a male athlete (two). Therefore, only six out of 265 articles referenced any impact on Title IX, and zero discussed Title IX in terms of the bylaw waivers except for sport sponsorship.

Similar results were found when looking at the top three most trafficked sports websites: Yahoo! Sports, ESPN, and Bleacher Report (Top 15, 2020). Using similar search terms as used on Nexis Uni across the same dates yielded five Yahoo! Sports articles, 10 ESPN articles, and two Bleacher Report articles. Content analysis revealed that zero articles discussed Title IX in reference to the bylaw waivers. While media outlets have reported on the waivers and a few have paid attention to the problems associated with sports sponsorship, none have looked deeper at the other bylaw waivers requested by Division I institutions to see what potential problems lurk beneath.

\section{NCAA Response and Requested Bylaw Waivers}

The NCAA formally responded to the escalating COVID-19 pandemic in early March by forming a coronavirus advisory panel. The panel and NCAA representatives reacted as the situation progressed, initially by allowing contests to continue as the Centers for Disease Control had not yet advised against them and then by limiting attendance. By March 12, however, the NCAA canceled the remaining winter and spring championships. Following the cancellation, the NCAA adjusted rules to help universities confront the pandemic's fallout, such as approving temporary blanket waivers for sport sponsorship and scheduling requirements, extending eligibility for spring-sport student athletes, and adjusting recruiting regulations, among others.

By April 10, commissioners had submitted their letter expressing their anxiety and formally requesting several bylaw waivers for a period of up to 4 years. Table 1

\section{Table 1 NCAA Bylaw Waiver Requests}

\begin{tabular}{ll}
\hline 20.9.9.3 & Football attendance requirements (FBS) \\
20.9.9.1 & Sports sponsorship (FBS) \\
20.9.9.2 & Football scheduling requirements (FBS) \\
20.9.9.4 & Additional financial aid requirements (FBS) \\
17.1.7.2.2.5 & Summer athletic activities (for basketball and football [FBS/FCS]) \\
20.9.6.3 & Minimum contests and participants requirements for sports sponsorship \\
20.9.7.1 & Scheduling requirement-Sports other than football, basketball, cross- \\
& country, men's swimming and diving, indoor and outdoor track and field, \\
and wrestling & Scheduling requirement-Cross-country, men's swimming and diving, \\
20.9.7.2 & indoor and outdoor track and field, and wrestling \\
31.3.4.1 & One third of contests in home arena (basketball) \\
\hline
\end{tabular}

Note . FBS = Football Bowl Subdivision; FCS = Football Championship Subdivision; NCAA = National Collegiate Athletic Association. 
outlines the requests (as cited in Thamel, 2020). Two weeks later, the Division I Council Coordination Committee decided it would not allow a blanket legislative waiver for the sport sponsorship requirement for Academic Year 2020-2021. Individual schools, however, could still request consideration (Hosick, 2020a). Then on May 6, the committee approved blanket waivers for three items: basketball and football summer athletic participation without enrollment in summer school (Bylaw 17.1.7.2.2.5), requirements for minimum financial aid (Bylaw 20.9.9.4), and reclassifying schools to count as Division I opponents. These waivers were made specifically in response to the requests made by the Division I conferences (Hosick, 2020c).

Out of the numerous changes and adjustments the NCAA has made, there are four bylaw waiver requests still positioned to have the most impact on women athletes: financial aid minimums (Bylaw 20.9.9.4), participant requirements (Bylaw 20.9.6.3), and scheduling requirements (Bylaws 20.9.7.1 and 20.9.7.2). Because the DI Council denied any blanket waiver for sport sponsorship in 2021, which represented the largest and most significant threat to Title IX compliance, it will not be discussed. In addition, by the end of May it appeared that more men's teams were being cut than women's, 16 and four, respectively, suggesting that sport sponsorship was not a large-scale threat (Beard, 2020). There are, however, still four bylaw waivers that can threaten a university's ability for Title IX compliance.

\section{Bylaw 20.9.9.4}

Bylaw 20.9.9.4, titled Additional Financial Aid Requirements, received a 1-year blanket waiver on May 6, making it effective from spring 2020 to spring 2021. The bylaw addresses financial aid and identifies two items FBS schools need to satisfy to provide scholarships to student athletes. First, schools need to award a minimum of $90 \%$ of football grants-in-aid over a 2 -year period. Second, schools must annually offer 200 athletic grants-in-aid or award at least $\$ 4$ million to student athletes (Division I Manual, 2019). Grant-in-aid, or athletic financial aid, comes in the form of scholarships, and the NCAA dictates the maximum number of scholarships each team receives. Within that allocation, there are two ways that scholarships can be awarded-either through head count or equivalency. Head count sports include men's basketball (13 scholarships) and football (85). Women's head count sports include basketball (15 scholarships), gymnastics (12), tennis (eight), and volleyball (12). For these sports, there is a required maximum number of scholarships that can be awarded, and each athlete receiving financial aid counts as one full scholarship. The remaining NCAA sports are deemed equivalency sports, and scholarships can be divided among any number of student athletes. For example, ice hockey has a maximum of 18 scholarships, but, theoretically, 36 student athletes could receive half of a scholarship. There is discretion with how financial aid can be awarded the institutional level, and there are no NCAA bylaws that mandate aid needs to be awarded at a gender-proportional rate. However, Title IX requires that female and male student athletes receive athletic scholarship dollars proportional to their participation within 1\% (Dear Colleague Letter, 1998).

This particular bylaw waiver extension is problematic because it threatens to continue, if not augment, a history of institutions underfunding women athletes and 
violating Title IX. In 1997, the National Women's Law Center alleged Title IX violations against 25 schools. Their complaint, filed with the Office of Civil Rights, argued that these schools provided a smaller proportion of financial aid to women athletes (George, 1999). In 2014, 75\% of Power 5 Conference schools (Atlantic Coast, Big Ten, Big 12, Pac-12, and Southeastern Conference) were not in numeric compliance with their financial aid (Kantor, 2016), mirroring a 75\% noncompliance rate among all Division I FBS schools (Osborne, 2017). At the Football Championship Subdivision (FCS), only $20 \%$ of the 114 institutions were in compliance with scholarship regulations. Scholarship discrepancies at both the FBS and FCS levels were largely due to overfunding male student athletes and providing disproportionate scholarship funding for women athletes (Osborne, 2017).

If schools were unable to uphold this bylaw even during times when COVID19 did not present such a financial challenge, what are they to do now? With the bylaw being waived, there is more flexibility to maintain scholarship disproportionality or even increase it. And with revenue as important as ever, it might make financial sense to some to maintain football and men's basketball scholarships, the most consistent revenue earners, above other teams' considerations. If the financial pot is low and there is only so much money to go around, women athletes will continue to be left out. The flexibility that this relaxed regulation provides can directly impact what women receive and what they do not. Research (e.g., George, 1999; Kantor, 2016; Osborne, 2017) suggests that women, historically, have been overlooked, and without proper oversight, this bylaw waiver could help further that imbalance and noncompliance.

\section{Bylaws 20.9.6.3, 20.9.7.1, and 20.9.7.2}

The additional three bylaws that threaten a university's ability to comply with Title IX include Bylaw 20.9.6.3 (Minimum Contests and Participants Requirements for Sports Sponsorship), Bylaw 20.9.7.1 (Scheduling Requirement-Sports Other Than Football, Basketball, Cross Country, Men's Swimming and Diving, Indoor and Outdoor Track and Field, and Wrestling), and Bylaw 20.9.7.2 (Scheduling Requirement-Cross Country, Men's Swimming and Diving, Indoor and Outdoor Track and Field, and Wrestling). These are all discussed in one section as they are all referenced under Bylaw 20.9, which focuses on Division I membership requirements, and both scheduling requirements explicitly reference Bylaw 20.9.6.3. While these waivers are still pending for 2020-2021, they all received a blanket waiver approval for 20192020, and, as will be discussed later, some conferences are already moving forward, assuming the waivers will pass.

Bylaw 20.9.6.3 outlines the minimum number of contests an intercollegiate team must annually engage in against 4-year institutions as well as the minimum number of participants required (Division I Manual, 2019). Table 2 outlines the bylaw requirements. Bylaw 20.9.7.1 states that for all sports other than football, basketball, cross-country, men's swimming and diving, indoor and outdoor track and field, and wrestling, $100 \%$ of the sports' contests should be scheduled and played against Division I opponents. Finally, Bylaw 20.9.7.2 states that in crosscountry, men's swimming and diving, indoor and outdoor track and field, and wrestling, at least $50 \%$ of the sports' contests must be scheduled and played against Division I opponents (Division I Manual, 2019). 


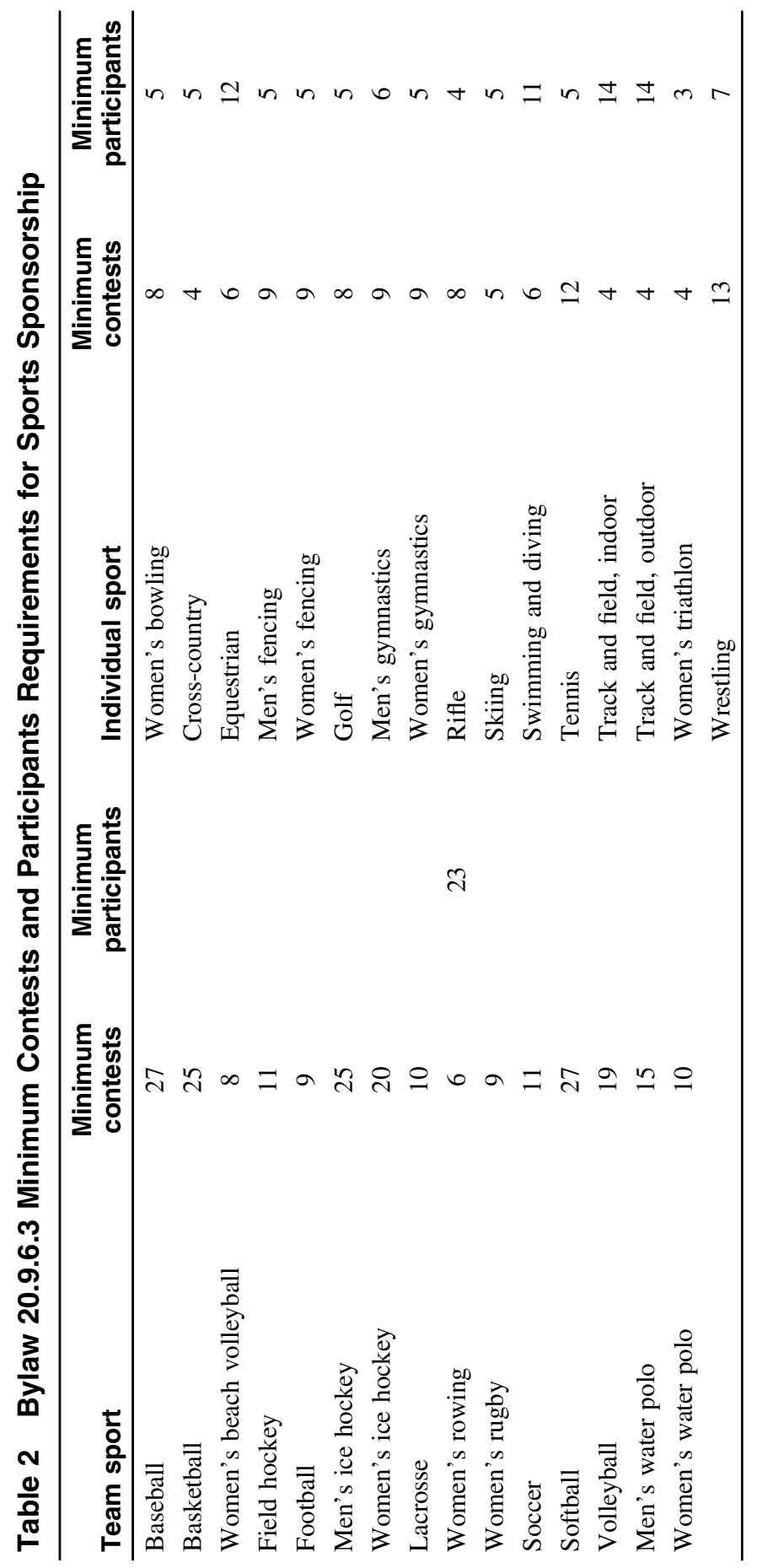


The number of required contests held against Division I opponents and scheduling are large concerns for Division I programs, with direct implications for finances. As conferences have realigned and scheduled travel can stretch thousands of miles, team transportation and equipment costs add up considerably; and it is not just the Division I commissioners and programs that think a waiver makes sense. A request for extending scheduling waivers beyond 2020 has also been sought by the Knight Commission on Intercollegiate Athletics. In late April, they requested scheduling relief for nonrevenue sports other than football and basketball. Their goal for more regional scheduling and less crosscountry or out-of-region scheduling is to reduce travel costs: "Waivers of these provisions would provide significant flexibility for conducting regular-season competition, which should result in substantial cost savings" (Schlabach, 2020, para. 4).

To be fair, there is a reason that relaxing the minimum contests could be reasonable. If various universities decide to cancel fall sports, then other schools still planning to compete will be left with fewer viable options. For example, on May 13 the California State University system decided to go almost fully online with class for the fall semester. Hours after this announcement, the California Collegiate Athletic Association suspended all competitions for the Fall 2020 season. Although this impacts its 12 members at the Division II level, it demonstrates how schools can choose to pull out, and, if they do, a team can be left with fewer competitors.

Relaxing contest and scheduling requirements, however, has the potential to tip athletics firmly in the favor of men and leave women on the side. Where the uncertainty and tension lie is in how athletic programs decide to handle the revenue and nonrevenue sports. The Big Sky Conference provides an example to demonstrate this concern. On May 11, the conference announced changes for the 20202021 academic year. First, the volleyball regular season conference schedule was reduced from 18 to 16 matches. Second, the women's soccer conference tournament was eliminated in favor of automatically advancing the team with the most points at the end of the season. This replaced the conference championship tournament that included six teams. Third, volleyball, softball, and tennis had their conference championship tournaments reduced in size. Volleyball went from eight teams to only allowing four, softball went from a six-team to a four-team tournament, and tennis went from a six-team tournament to four (Guernsey, 2020). With the exception of men's tennis, these changes all directly impact women's sports.

The results of these bylaw waivers pose a Title IX concern if women's sports are reduced in such a way that it impacts the availability, quality, kind of benefits, kind of opportunities, and kind of treatment that women student athletes receive versus men student athletes. To be clear, Title IX does not require that men's and women's programs offer identical experiences, but they are required to provide equivalent treatment, services, and benefits ("Requirements Under Title IX," n.d.). In the case of the Big Sky Conference, the women's teams are clearly impacted, whereas men's teams are left relatively unscathed. While athletic directors surely have financial arguments about maintaining revenue sports' schedules, such as those for football and men's basketball, if they are left untouched, are women and men receiving similar quality athletic experiences? 


\section{Conclusion}

The history of athletic departments' noncompliance with Title IX is well documented. As NCAA programs embark into unchartered territory due to COVID-19, oversight is mandatory to make sure that discrimination does not serve as a way to keep athletic departments alive. This is not to say that commissioners and athletic directors that ask for waivers or receive regulatory relaxation are motivated by a desire to not comply with Title IX requirements. Furthermore, even if the NCAA relaxes their bylaws, federal legislation will still be enforced and supersedes organizational rules. However, without proper oversight, Division I athletic programs could either directly or indirectly cut many programs to the bare bones while allowing revenue teams to play full schedules with full numbers of participants and offer more financial aid.

There are three key ways to help minimize problems with Title IX as the bylaw waivers are enacted. First, the Department of Education should appoint a person, or a task force, to oversee the bylaw changes. This person, or group, could also create and disperse official statements for compliance officers to help universities navigate the balance between upholding federal legislation while making fiscal changes. Second, athletic departments and conferences should ensure that if women's schedules and conference competitions are cut, that men's are reduced as well. This does not have to be the same for all teams, but if items for women's teams are cut, then similar cuts should be done to men's teams for equivalency purposes. For example, while the Big Sky conference reduced contest and scheduling requirements for several women's teams in late May, they reduced men's and women's basketball equally. Both teams will play a 16-game conference schedule, as opposed to the traditional 20 in-conference games. Third, related to financial aid requirements, football programs should reduce their scholarships from the 85 maximum they are allowed. An estimated cost of an average year of attendance at a Division I FBS school, counting tuition, room, board, and books/supplies, is $\$ 39,747$ (Jennings, 2012). During a time of extreme financial risk, reducing 5-7 scholarships on the football team could help the financial aid imbalance between men's and women's teams and contribute hundreds of thousands of dollars to nonrevenue teams with, arguably, little overall impact.

As athletic departments move into a "new normal," tough decisions will need to be made. This is a significant risk and everyone, including commissioners, coaches, athletic directors, and communication and sport scholars, must be aware. Light must be shone on potential problems with NCAA bylaw waivers so thousands of women athletes do not lose out and athletic programs do not further threaten Title IX compliance.

\section{References}

Beard, A. (2020, May 27). Title IX major factor for colleges looking at sports cuts. Washington Post. Retrieved from https://www.washingtonpost.com/sports/soccer/ title-ix-major-factor-for-colleges-looking-at-sports-cuts/2020/05/27/efc340f6-a05611ea-be06-af5514ee0385_story.html 
Burnsed, B. (2015, September 18). Athletics departments that make more than they spend still a minority. NCAA. Retrieved from http://www.ncaa.org/about/resources/mediacenter/news/athletics-departments-make-more-they-spend-still-minority

Dear colleague letter: Bowling Green State University. (1998, July 23). U.S. Department of Education. Retrieved from https://www2.ed.gov/about/offices/list/ocr/docs/bowlgrn.html

Division I manual. (2019). NCAA. Retrieved from https://web3.ncaa.org/lsdbi/reports/ getReport/90008

George, B.G. (1999). Title IX and the scholarship dilemma. Marquette Sports Law Review, 9(2), 273-285.

Guernsey, M. (2020, May 11). Big sky announces major changes to upcoming sports seasons. Idaho State Journal. Retrieved from https://www.idahostatejournal.com/ sports/isu/big-sky-announces-major-changes-to-upcoming-sports-seasons/article_ ebb8296d-cc70-5420-be00-9325a9aa9943.html

Hosick, M.B. (2020a, April 24). DI Council continues COVID-19 impact discussions. NCAA. Retrieved from https://www.ncaa.org/about/resources/media-center/news/dicouncil-continues-covid-19-impact-discussions

Hosick, M.B. (2020b, April 30). DI Board of Directors and Presidential Forum discuss future of division. NCAA. Retrieved from http://www.ncaa.org/about/resources/mediacenter/news/di-board-directors-and-presidential-forum-discuss-future-division

Hosick, M.B. (2020c, May 6). DI Council Coordination Committee approves blanket waiver requests. NCAA. Retrieved from https://www.ncaa.org/about/resources/media-center/ news/di-council-coordination-committee-approves-blanket-waiver-requests

Jenkins, W. (2019, November 1). Hundreds of colleges may be out of compliance with Title IX. Here's why. Chronicle of Higher Education, 66(9), 1.

Jennings, K. (2012, March 8). What's a college football scholarship worth, anyway? Bleacher Report. Retrieved from https://bleacherreport.com/articles/1094781-sowhats-a-college-football-scholarship-worth-anyway

Kantor, M.K. (2016, Spring). Title IX compliance vs. NCAA scholarship limits (Master's thesis). Carolina Digital Repository, University of North Carolina, Chapel Hill, NC. Retrieved from https://cdr.lib.unc.edu/concern/dissertations/pg15bg088

Osborne, B. (2017). Failing to fund fairly: Title IX athletics scholarships compliance. Tennessee Journal of Race, Gender, \& Social Justice, 6(1), 83-104.

Requirements under Title IX of the education amendments of 1972. (n.d.). U.S. Department of Education. Retrieved from https://www2.ed.gov/about/offices/list/ocr/docs/interath. html

Schlabach, M. (2020, April 29). Non-revenue sports asking NCAA for scheduling relief. $E S P N$. Retrieved from https://www.espn.com/college-sports/story/_/id/29114128/ non-revenue-sports-asking-ncaa-scheduling-relief

Staurowsky, E.J., \& Weight, E. (2011). Title IX literacy: What coaches don't know and need to find out. Journal of Intercollegiate Sport, 4(2), 190-209. doi:10.1123/jis.4.2.190

Thamel, P. (2020, April 14). With budgets tightening due to coronavirus fallout, will more college sports be cut? Yahoo! Sports. Retrieved from https://sports.yahoo.com/withbudgets-tightening-will-more-college-sports-be-cut-204423901.html

Top 15 most popular sports websites. (2020, February 1). Ebizmba. Retrieved from http:// www.ebizmba.com/articles/sports-websites 